\title{
Immunologic and Nonimmunologic Generation of Superoxide from Mast Cells and Basophils
}

\author{
William R. Henderson and MiChael Kaliner, Laboratory of Clinical \\ Investigation, National Institute of Allergy and Infectious Diseases \\ National Institutes of Health, Bethesda, Maryland 20014
}

\begin{abstract}
A B S T RACT Mediator release from rat peritoneal and human lung mast cells as well as human leukemic basophils was examined to determine whether superoxide $\left(\mathrm{O}_{2}^{-}\right)$was concomitantly generated. Immunologic or nonimmunologic stimulation of each preparation induced parallel release of histamine and $\mathrm{O}_{2}^{-}$within 2 min. $\mathrm{O}_{2}^{-}$production was quantitated by superoxide dismutase (SOD)-inhibitable chemiluminescence and cytochrome $c$ reduction. SOD was detected in basophil and mast cell lysates and was also released by rat mast cells stimulated by anti-IgE. Secretory granules isolated from purified rat mast cells released histamine, $\mathrm{O}_{2}^{-}$, and SOD upon exposure to cations. Thus, both superoxide radicals and SOD may play a role in host defenses involved in immediate hypersensitivity reactions.
\end{abstract}

\section{INTRODUCTION}

The superoxide radical, $\mathrm{O}_{2}^{-1}, 1$ and its potent byproducts (singlet oxygen and hydroxyl radicals) appear to play a major role in the microbicidal activity of phagocytic cells (1-8). The absence of $\mathrm{O}_{2}^{-}$production may be responsible for the defective killing of bacteria by polymorphonuclear leukocytes in chronic granulomatous disease $(5,7,8)$. In contrast to its normal role in host defenses, $\mathrm{O}_{2}^{-}$generation has been implicated in the pathogenesis of paraquat poisoning suggesting that under certain conditions it may be deleterious to host tissues (9). The enzyme, superoxide dismutase (SOD) specifically scavenges $\mathrm{O}_{2}^{-}$and therefore may be capable of protecting tissues from this radical's toxicity (10).

Received for publication 11 February 1977 and in revised form 7 September 1977.

${ }^{1}$ Abbreviations used in this paper: BSA, bovine serum albumin; NBT, nitroblue tetrazolium; RPMC, rat peritoneal mast cells; SOD superoxide dismutase; $\mathrm{O}_{2}^{-}$, superoxide radical, TEMED, $N, N, N,{ }^{1} N,{ }^{1}$ tetramethylethylenediamine, Tyr-gel, Tyrode's buffer $0.1 \%$ gelatin.
One of the major pathways associated with $\mathrm{O}_{2}^{-}$ production involves activation of the hexose monophosphate shunt resulting in production of reduced pyridine nucleotides (8). Both the human peripheral basophil and lung mast cell and the rat peritoneal mast cell release histamine, eosinophil chemotactic factor of anaphylaxis, and other chemical mediators as a consequence of the reaction of antigen with cellbound antibody of the IgE class (11-16). The biochemical reactions involved in both the nonimmunologically and immunologically activated secretory processes have been partially elucidated and the requirement for energy consistently demonstrated (14, $17,18)$. The energy pathways available in rat mast cells and human basophils and mast cells include aerobic and anaerobic glycolysis, oxidative phosphorylation, and hexose monophosphate shunt activity $(14,17,19,20)$. Therefore it seemed possible that $\mathrm{O}_{2}^{-}$might be generated as a consequence of energy utilization during the secretion of mediators.

Employing the ability of $\mathrm{O}_{2}^{-}$to reduce cytochrome $c$ $(2,6)$ and to produce photon emissions resulting from electronically excited molecules (generated from $\mathrm{O}_{2}^{-}$: mediated reactions, from $\mathrm{H}_{2} \mathrm{O}_{2}$, or secondary to relaxation of singlet oxygen $\left({ }^{1} \mathrm{O}_{2}\right)$ resulting from disproportionation of $\left.\mathrm{O}_{2}^{-}\right)(1,21)$, the presence of both $\mathrm{O}_{2}^{-}$and histamine was detected after immunologic and nonimmunologic stimulation of rat mast cells, human basophils, and human lung tissue. The enzyme capable of catalyzing the spontaneous dismutation of $\mathrm{O}_{2}^{-}$to $\mathrm{O}_{2}$ and $\mathrm{H}_{2} \mathrm{O}_{2}$ $(22,23)$, SOD was also demonstrated. Further, both SOD and $\mathrm{O}_{2}^{-}$production were found in isolated secretory granules from rat mast cells.

\section{METHODS}

Sodium heparin (beef lung) (Upjohn Co., Kalamazoo, Mich.); histamine diphosphate, compound 48/80, nitroblue tetrazolium ([NBT] grade III), ferricytochrome $c$-type VI (from horse heart), xanthine, SOD $(3,000 \mathrm{U} / \mathrm{mg}$ protein as assayed by the method of McCord, and Fridovich) [23]) (Sigma 
Chemical Co., St. Louis, Mo.); xanthine oxidase (C. F. Boehringer and sons $\mathrm{GmbH}$, Mannheim, West Germany); riboflavin, and $N, N, N,{ }^{1} N^{1}$ tetramethylethylenediamine (TEMED) (Hoechst-Roussel Pharmaceuticals Inc., Somerville, N. J.); Hypaque-M, 90\% (Winthrop Laboratories, New York); Ficoll 400 (Pharmacia Fine Chemicals Inc., Piscataway, N. J.); and rabbit anti-human IgE (€-chain specific) (Behring Diagnostics, American Hoechst Corp., Somerville, N. J.) were obtained from the manufacturers. Ragweed antigen E was supplied by the Research Resources Branch, National Institute of Allergy and Infectious Diseases, Bethesda, Md. Sheep anti-rat IgE was kindly supplied by Dr. Henry Metzger (National Institutes of Health, Bethesda, Md.). The sheep anti-rat IgE (anti-IgE) was absorbed with IgE-free newborn rat serum and produced one line of identity against rat IgE myeloma protein when examined by immunoelectrophoresis. A 1:50 dilution of anti-IgE induced an average of $31.5 \%$ release of histamine from a mixed population of rat peritoneal cells (5-10\% mast cells) whereas a 1:10 dilution produced an average of $39.2 \%$ histamine release from purified rat mast cells. The anti-IgE reaction was noncytotoxic as evidenced by $39 \%$ histamine release without lactic dehydrogenase release ( $<3 \%$ above background) (24) and by the ability of $>90 \%$ of the immunologically activated cells to exclude trypan blue dye (25).

Preparation of purified rat peritoneal mast cells (RPMC). Mast cells were collected by rinsing the peritoneal cavities of 200-g-male Sprague-Dawley rats with $12 \mathrm{ml}$ of Tyrode's buffer-0.1\% gelatin (Tyr-gel) containing $10 \mathrm{U} / \mathrm{ml}$ heparin. Neutrophilic polymorphonuclear leukocytes are absent from normal rat peritoneal fluid $(26,27)$. The mixed cell suspensions contained 4-5\% mast cells, 15-20\% eosinophilic leukocytes, and 80-85\% mononuclear cells. Smear preparations of peritoneal fluid fixed in 10\% formalin:90\% alcohol, and stained with hematoxylin and eosin revealed no platelets. Similarly, no platelets were seen in phasecontrast microscope examination of the mixed peritoneal cell suspensions.

Cells from 10 animals were pooled and purified according to the method of Sullivan et al. (28). The mixed cell suspensions were centrifuged at $50 \mathrm{~g}$ for $7 \mathrm{~min}$ at $25^{\circ} \mathrm{C}$, the supernate decanted, the cell pellet pooled, and resuspended in $10 \mathrm{ml}$ Tyr-gel. 2-ml aliquots of the cell suspension were layered over $4 \mathrm{ml}$ of $38 \%$ bovine serum albumin (BSA) (wt/vol) in $15 \times 120-\mathrm{mm}$ polystyrene centrifuge tubes and allowed to settle for $25 \mathrm{~min}$ at $25^{\circ} \mathrm{C}$. The mast cells were centrifuged into the BSA cushion at $450 \mathrm{~g}$ for $20 \mathrm{~min}$ at $25^{\circ} \mathrm{C}$ and the supernate and interface aspirated. The BSA-cell pellet was washed twice and resuspended in Tyr-gel. The resulting mast cell isolates (RPMC) were always of $>90 \%$ purity. The contaminating cells consisted of $<10 \%$ mononuclear cells and $<1 \%$ eosinophilic leukocytes. No platelets were seen.

Preparation of mast cell-free rat peritoneal cells. Because mononuclear and eosinophilic leukocytic cells have been shown to generate superoxide anions after appropriate stimulation $(4,29-32)$, peritoneal cell suspensions devoid of mast cells were prepared to test whether superoxide production in the purified rat mast cell suspensions could be attributed solely to mast cell stimulation. By the method of Fawcett (33), normal adult rats were injected intraperitoneally with $20 \mathrm{ml}$ of distilled water producing osmotic lysis of cellular elements. 5 days later, peritoneal fluid was collected as described by rinsing the peritoneal cavities with Tyr-gel containing heparin. The peritoneal cell population consisted of 70-75\% mononuclear cells and 25-30\% eosinophilic leukocytes. No mast cells were seen in these preparations because of the slow regeneration (up to 3 mo after osmotic lysis) of the mast cells from their peritoneal omental fibroblast precursors (33).

Additional mast cell-free preparations were obtained by retaining the interface layer of cells from the centrifuged $38 \%$ BSA gradient purifications of mixed cell suspensions. Such interface preparations contained $<0.5 \%$ mast cells.

Isolation of mast cell granules. Membrane-free granules were isolated from purified rat mast cells according to the method of Uvnäs et al. (34). $5 \times 10^{6}$ RPMC were centrifuged at $400 \mathrm{~g}$ for $10 \mathrm{~min}$ at $4^{\circ} \mathrm{C}$ and resuspended in 60 $\mathrm{ml}$ deionized water, adjusted to $\mathrm{pH} 7.1$, with $0.1 \mathrm{M} \mathrm{NaOH}$ (pH meter, model 26, Radiometer Co., Copenhagen, Denmark). The $\mathrm{pH}$ of the suspension was carefully maintained at 7.1 with $0.1 \mathrm{M} \mathrm{NaOH}$ without serious alkalinization of the mixture during a 15-min period of gentle agitation. Large cellular debris was separated by centrifugation at $400 \mathrm{~g}$ for $10 \mathrm{~min}$ at $4^{\circ} \mathrm{C}$. The granule-containing supernate was centrifuged at $3,000 \mathrm{~g}$ for $20 \mathrm{~min}$ at $4^{\circ} \mathrm{C}$ and the granular pellet was resuspended in deionized water, $\mathrm{pH}$ 7.1. The granular isolate was fixed in $3 \%$ glutaraldehyde, embedded in Maraglas (Polysciences, Inc., Warrington, Pa.), thin sectioned, and stained with uranyl acetate. The sections were examined employing a Phillips EM 300 (Phillips Electronic Instruments, Mount Vernon, N. Y.). The addition of Tyrode's buffer to the granular isolate released $99.5 \%$ of the total granular histamine.

Purification of human basophils. Human basophilic leukocytes were obtained from a patient with basophilic leukemia kindly referred by Dr. Charles Jaffe (Georgetown University, Washington, D. C.). The patient (L. W.) had a peripheral leukocyte count ranging from 25,000 to $100,000 / \mathrm{ml}$ with $40-60 \%$ mature basophils. The basophils were purified from $50 \mathrm{ml}$ of blood anticoagulated with EDTA (0.1 M final concentration). The blood was diluted (1:2) with Hanks' balanced salt solution (lacking calcium, magnesium, and phenol red) and layered over 12 $\mathrm{ml}$ of $33 \%$ Hypaque, $9 \%$ Ficoll $(1: 2$, vol/vol). These suspensions were centrifuged at $450 \mathrm{~g}$ for $40 \mathrm{~min}$ at $25^{\circ} \mathrm{C}$. The interface layer containing basophils and mononuclear cells were collected and washed three times with Hank's balanced salt solution. The resulting cell suspension contained $75 \%$ basophils, $25 \%$ monocytes and lymphocytes.

Preparation of human lung tissue. Human lung tissue obtained at the time of cancer resection was studied for antigen-induced release of histamine and $\mathrm{O}_{2}^{-}$(35). Macroscopically normal areas of lung tissue were dissected free of pleura, large bronchi, and blood vessels, fragmented into 200-mg replicates, washed extensively with Tyrode's buffer, and incubated for $18 \mathrm{~h}$ at room temperature in undiluted serum from a patient allergic to ragweed (F. P.). For mediator release, lung fragments were either challenged with 1:50 dilution of rabbit anti-human IgE or with $0.5 \mu \mathrm{g} / \mathrm{ml}$ antigen $\mathrm{E}$ for $30 \mathrm{~min}$ at $37^{\circ} \mathrm{C}$. Residual tissue histamine was extracted from the lung fragments by osmotic lysis in distilled water for $30 \mathrm{~min}$.

Histamine bioassay. Histamine was assayed on the atropinized guinea pig ileum (12). Histamine release from mast cells or basophils was assayed from preparations either maintained in parallel with samples for $\mathrm{O}_{2}^{-}$production or in the same supernates utilized for $\mathrm{O}_{2}^{-}$assay. The presence of cytochrome $c, 0.1 \mathrm{mM}$, had no effect on the bioassay of histamine. In those samples run in parallel, $0.4-\mathrm{ml}$ suspensions of Tyr-gel containing 50,000 basophils or mast cells, or 200 -mg lung fragments were placed in $10 \times 75-\mathrm{mm}$ polypropylene tubes and warmed to $37^{\circ} \mathrm{C}$ for $10 \mathrm{~min}$. These suspensions were then challenged with the appropriate stimulating agent $(48 / 80$, anti-IgE, or ragweed antigen E) with a final reaction volume of $0.5 \mathrm{ml}$. The reaction 
was terminated by addition of $2.5 \mathrm{ml}$ of iced Tyr-gel and the suspensions immediately centrifuged at $1,500 \mathrm{~g}$ for 5 min at $4^{\circ} \mathrm{C}$. The supernates were retained for measurement of histamine released and cell pellets were lysed in $3.0 \mathrm{ml}$ of distilled water for determination of residual histamine. The percentage of histamine release was expressed as the ratio of histamine released compared to total histamine content (released plus residual histamine). Secretory granules isolated in deionized water were suspended in Tyr-gel to liberate their histamine content. Such suspensions were then centrifuged at $3,000 \mathrm{~g}$ for $20 \mathrm{~min}$ at $4^{\circ} \mathrm{C}$ and the supernates assayed for histamine release. The pellets were sonicated and then freeze-thawed three times before being assayed for residual histamine content.

Measurement of chemiluminescence. Light emission was studied according to the method of Allen et al. (1) with an unrefrigerated Beckman LS-liquid scintillation counter (Beckman Instruments, Inc., Fullerton, Calif.) at ambient temperature $\left(30^{\circ} \mathrm{C}\right)$ operating in the out of coincidence mode, and using the tritium window setting with a single activated photomultiplier tube. Experiments were performed under red actinic light in polypropylene tubes $(10 \times 55 \mathrm{~mm})$ placed in glass scintillation vials that had been kept in the dark for $24 \mathrm{~h}$.

The background (empty counting chamber) counts per minute were $7,000-8,000$, the cell suspensions usually produced an additional $3,000-4,000 \mathrm{cpm}$, and the specific chemiluminescence induced by the experimental manipulations will be expressed as net increase in counts per minute after subtracting background (stimulated cell light emission minus unstimulated cell light emission).

The protocol employed to maintain the samples at a constant $37^{\circ} \mathrm{C}$ temperature in the $30^{\circ} \mathrm{C}$ ambient temperature of the liquid scintillation counter consisted of warming to $37^{\circ} \mathrm{C}$ multiple separate vials containing cell suspensions in $1 \mathrm{ml}$ of Tyr-gel $\left(1.25 \times 10^{6}\right.$ mast cells, $1.25 \times 10^{6}$ mast cell-free rat peritoneal cells, $5 \times 10^{6}$ basophils, or $200 \mathrm{mg}$ lung fragment). The vials were counted for $24 \mathrm{~s}$ and returned to the water bath for a 2 -min incubation at $37^{\circ} \mathrm{C}$. Before and after each quantitation of luminescence, the vials were agitated to increase the oxygen saturation. Each vial was absent from the water bath for $<1 \mathrm{~min}$ every $7 \mathrm{~min}$.

The warming-counting cycle was repeated until baseline counts per minute were constant $\pm 5 \%$ variation (usually $10 \mathrm{~min}$ or less). The counts per minute of unstimulated samples were found to remain unchanged $( \pm 5 \%)$ during the 20-60 min of each experiment. At time 0 , after a constant base line of the sample had been obtained, the stimulating agent (48/80, anti-IgE, or ragweed antigen $\mathrm{E})$ suspended in Tyr-gel was simultaneously added to quadruplicate samples. The time-course of luminescence was determined by counting individual samples at varying intervals from time 0 to 20-60 min after stimulation. In each experiment, identical cell preparations challenged in the presence of $7 \mu \mathrm{g} / \mathrm{ml}$ SOD were also assayed. Control tubes of 1 ml Tyr-gel plus stimulating agent alone $(48 / 80$, anti-IgE, or ragweed antigen $E$ ) in the absence of cells did not generate any chemiluminescence. Addition of ragweed antigen $E$ to unsensitized human lung fragments failed to induce any chemiluminescence.

Chemiluminescence of granule preparations was measured in the same manner after addition of Tyr-gel to isolated granule pellets (corresponding to $5 \times 10^{6}$ intact mast cells) which had attained stable base-line counts per minute.

Ferricytochrome c reduction. The reductant properties of superoxide were measured by the capacity of $\mathrm{O}_{2}^{-}$to reduce ferricytochrome $c$ as described by Babior et al. (2). The kinetic experiments were performed employing cell sus- pensions $\left(1.25 \times 10^{6}\right.$ purified mast cells, $1.25 \times 10^{6}$ mast cell-free rat peritoneal cells, or $5 \times 10^{6}$ human leukemic basophils) in Tyr-gel containing cytochrome $c$ (final reaction concentration $0.1 \mathrm{mM}$ ) in 6-ml polyethylene syringe barrels. The ejection end of the syringe was tightly closed with a $13-\mathrm{mm}$ cellulose acetate filter with a $0.45-\mu \mathrm{m}$ pore size (HATF 1300, Millipore Corp., Boston, Mass.). After a 10-min warming period at $37^{\circ} \mathrm{C}$, the stimulating agent (anti-IgE, $48 / 80$, or ragweed antigen $E$ ) suspended in Tyr-gel was added to the cell suspension producing a final volume of 4.0 $\mathrm{ml}$. The time-course of cytochrome $c$ reduction was determined by challenging quadruplicate or sextuplicate samples and ejecting $1-\mathrm{ml}$ cell-free samples from the syringes through the filter at varying time intervals from 0 to $60 \mathrm{~min}$. A $1.0-\mathrm{ml}$ sample of cell-free supernate was ejected from the syringe immediately after challenging the cell suspension and utilized as a zero-time control. Additional controls in each experiment consisted of (a) $0.1 \mathrm{mM}$ cytochrome $c$ alone; (b) $0.1 \mathrm{mM}$ cytochrome $c$ plus stimulating agent; and (c) $0.1 \mathrm{mM}$ cytochrome $c$ plus the cell suspension without the addition of the stimulating agent. The control tubes were manipulated identically with the experimental samples except that an equal quantity of Tyr-gel rather than the stimulating agent was added at zero time.

Cytochrome $c$ reduction by isolated granules was measured by addition of a granule pellet (corresponding to $5 \times 10^{6}$ intact mast cells) to a suspension of $0.1 \mathrm{mM}$ cytochrome $c$ and Tyr-gel solution in a $4.0-\mathrm{ml}$ total volume. 1.0 $\mathrm{ml}$ was immediately withdrawn and kept at $4^{\circ} \mathrm{C}$ as the zerotime control and the remaining granule mixture incubated for $20 \mathrm{~min}$ at $37^{\circ} \mathrm{C}$. Both set of tubes were then centrifuged at $3,000 \mathrm{~g}$ for $20 \mathrm{~min}$ at $4^{\circ} \mathrm{C}$ to obtain granule-free supernates for spectrophotometric analysis. Cytochrome $c$ reduction by isolated granules was also determined in the presence of 7 $\mu \mathrm{g} / \mathrm{ml}$ SOD.

The cytochrome $c$ reducing capacity of antigen-challenged human lung tissue was assayed in a manner similar to that of the granule preparations. $200-\mathrm{mg}$ fragments of IgE-sensitized human lung tissue were warmed to $37^{\circ} \mathrm{C}$ for $10 \mathrm{~min}$ in Tyr-gel containing cytochrome $c(0.1 \mathrm{mM}$ final concentration). Ragweed antigen $\mathrm{E}(0.5 \mu \mathrm{g} / \mathrm{ml})$ or anti-human IgE (1:50) was added bringing the final volume to $4.0 \mathrm{ml}$. A $1.0-\mathrm{ml}$ sample was removed immediately (zero-time control) and the remaining $3.0 \mathrm{ml}$ incubated for $20 \mathrm{~min}$ at $37^{\circ} \mathrm{C}$. After $20 \mathrm{~min}$, the supernate was removed and analyzed spectrophotometrically. Addition of ragweed antigen E to unsensitized lung fragments failed to induce cytochrome $c$ reduction. Control fragments in the presence of cytochrome $c(0.1$ $\mathrm{mM}$ ) but without the addition of the stimulating agent were evaluated in parallel with the experimental sample. Additional controls included challenge of lung fragments in the presence of $7 \mu \mathrm{g} / \mathrm{ml}$ SOD.

Nanomoles of cytochrome $c$ reduced were calculated from the maximal increase in absorbance measured (Gilford 250 spectrophotometer, Gilford Instrument Laboratories Inc., Oberlin, Ohio) using an absorption coefficient of $21.1 / \mathrm{mM}$ per $\mathrm{cm}$ (6). The absorption spectrum of the zero-time control was routinely analyzed and the point of maximum absorption (usually 549 or $550 \mathrm{~nm}$ ) was employed in that experiment. Before the determination of the maximum absorption of each sample, the spectrophotometer was blanked to zero by the appropriate zero-time control. Therefore, the data for each sample reflects the increase in absorbance above that in the zero-time control. Superoxide production was calculated as the difference between the amount of cytochrome $c$ reduction obtained between parallel samples in the absence and presence of SOD. Nanomoles of cytochrome $c$ reduced by unstimulated cells alone (averaging 
1-1.5 nmol/10 $10^{6}$ cells per experiment) were subtracted from each experimental sample. The results are expressed as net nanomoles of SOD-inhibitable cytochrome $c$ reduced per $10^{6}$ mast cells, $10^{6}$ basophils, or $200 \mathrm{mg}$ lung tissue. The nanomoles of cytochrome $c$ generated by the addition of cations to secretory granules of $5 \times 10^{6}$ purified mast cells is expressed as the total nanomoles of cytochrome $c$ reduced by this preparation. No cytochrome $c$ reduction was induced by anti-IgE, $48 / 80$, or antigen $E$ in the absence of cells. SOD $(7 \mu \mathrm{g} / \mathrm{ml})$ which had been boiled for $10 \mathrm{~min}$ or BSA $\left(7 \mu \mathrm{g} / \mathrm{ml}\right.$ ) had no effect on $\mathrm{O}_{2}^{-}$production (as determined by cytochrome $c$ reduction) of purified rat mast cells stimulated by either $48 / 80$ or anti-IgE.

SOD determination. SOD was detected by two independent assays: $(a)$ its inhibition of NBT reduction as assessed utilizing acrylamide gels $(22)$; and $(b)$ its inhibitory action on the xanthine/xanthine oxidase-mediated reduction of cytochrome $c$ (36). Lysates of purified basophil $\left(2.5 \times 10^{6}\right.$ cells) and mast cell $\left(1.25 \times 10^{6}\right.$ cells $)$ suspensions were prepared by distilled water lysis followed by sonication for $60 \mathrm{~s}$ (Disontegrator system 40, Heat Systems-Ultrasonics, Inc., Plainview, N. Y.) and freeze-thawing three times. Isolated mast cell granule preparations (obtained from 5 $\times 10^{6} \mathrm{RPMC}$ ) were placed in Tyr-gel, similarly sonicated, and then freeze-thawed. Particulate matter was removed from the three preparations by centrifugation at $20,000 \mathrm{~g}$ for $10 \mathrm{~min}$ at $4^{\circ} \mathrm{C}$. The supernates were suspended in $5-\mathrm{mM}$ Tris-glycine buffer, $\mathrm{pH} 6$, containing $30 \%$ sucrose, and then placed on $7.5 \%$ polyacrylamide gels that were both chemically polymerized and photopolymerized with TEMED, ammonium persulfate, and riboflavin $(22,37)$. After electrophoresis at $2 \mathrm{~mA}(90-120 \mathrm{~V})$, the gels were bathed initially with $2.45 \mathrm{mM}$ NBT for $20 \mathrm{~min}$, followed by a solution consisting of $28 \mathrm{mM}$ TEMED, $28 \mu \mathrm{M}$ riboflavin, and $36 \mathrm{mM}$ potassium monophosphate for $15 \mathrm{~min}$. Illumination of the gels with a 15-W fluorescent lamp caused photooxidation of the TEMED and photoreduction of the riboflavin. $\mathrm{O}_{2}^{-}$produced by interaction of $\mathrm{O}_{2}$ with the reduced flavin reduced the NBT present on the gels to the blue formazan except in areas containing SOD which remained achromatic. The gels were compared with reference gels electrophoresed with $2 \mu \mathrm{g}$ SOD.

To determine whether SOD is released as a consequence of immunologic stimulation, $5 \times 10^{6}$ purified rat mast cells were incubated with anti-IgE $(1: 10)$ in a total volume of $0.4 \mathrm{ml}$ Tyr-gel for $10 \mathrm{~min}$ at $37^{\circ} \mathrm{C}$. The suspensions were centrifuged at $1,500 \mathrm{~g}$ for $5 \mathrm{~min}$ at $4^{\circ} \mathrm{C}$ and the supernate assayed for SOD activity on the acrylamide gels.

The reduction of cytochrome $c$ by xanthine oxidase using xanthine as a substrate under aerobic conditions is mediated by superoxide (36). The interaction of xanthine oxidase 3.3 $\mathrm{nM}$ with xanthine $33 \mu \mathrm{m}$ in $2 \mathrm{ml}$ of sodium carbonate buffer $(\mathrm{pH} \mathrm{10})$ reduced ferricytochrome $c 0.1 \mathrm{mM}$ at an average rate of $0.20 \mathrm{nmol} / \mathrm{min}$ at $25^{\circ} \mathrm{C}(23,36)$. Concentrations of SOD $>0.5 \mu \mathrm{g} / \mathrm{ml}$ inhibited the reaction. Freeze-thawed suspensions of isolated mast cell granule preparations were compared with varying amounts of SOD in the xanthine/ xanthine oxidase assay to quantitate SOD activity.

Statistical analysis. Each experiment consisted of duplicate samples, was repeated multiple times, and the data reported herein represent the mean $\pm S E M$ of the combined experiments.

\section{RESULTS}

48/80 Induced release. Purified RPMC incubated with $1 \mu \mathrm{g} / \mathrm{ml} 48 / 80$ were found to release $40-60 \%$ of their histamine within $60 \mathrm{~s}$ without cytotoxicity (lactic dehydrogenase release $<3 \%$ above background and $>90 \%$ exclusion of trypan blue by the activated cells). Because concentrations of $48 / 80>1 \mu \mathrm{g} / \mathrm{ml}$ induced loss of trypan blue exclusion, $1 \mu \mathrm{g} / \mathrm{ml} 48 / 80$ was used for all chemiluminescence and cytochrome $c$ reduction studies of rat mast cells.

To determine if the superoxide radical, $\mathrm{O}_{2}^{-}$, was released coincidentally with histamine, purified RPMC $\left(1.25 \times 10^{6}\right)$ were challenged with $1 \mu \mathrm{g} / \mathrm{ml} 48 / 80$ and the release of mediators analyzed kinetically (Fig. 1). Histamine release was detected within $15 \mathrm{~s}$ of the addition of 48/80 $(1 \mu \mathrm{g} / \mathrm{ml})$ and achieved maximum release $(60.5 \%)$ by $30-45 \mathrm{~s}$. Histamine released $(60 \%$ maximum) from mast cells challenged in the presence of SOD $(7 \mu \mathrm{g} / \mathrm{ml})$ demonstrated parallel kinetics. Cytochrome $c$ reducing capacity was observed within $15 \mathrm{~s}$ of 48/80 addition, rapidly increased through $30-60 \mathrm{~s}$, and plateaued thereafter (maximal cytochrome $c$ reduction of $32.4 \pm 2.6 \mathrm{nmol} / 10^{6}$ mast cells) much the same as histamine release. The presence of SOD $(7 \mu \mathrm{g} / \mathrm{ml})$ prevented $>95 \%$ of the reducing capacity. Neither SOD which had been boiled for 10 min nor BSA ( 7 $\mu \mathrm{g} / \mathrm{ml}$ ) had any effect on the capacity of either mast cell or xanthine/xanthine oxidase generated $\mathrm{O}_{2}^{-}$to reduce cytochrome $c$. A peak of light emission was appreciated $30-45 \mathrm{~s}$ after $48 / 80$ challenge $(4,752$ $\pm 221 \mathrm{cpm} / 10^{6}$ mast cells) which was totally abolished by the addition of $7 \mu \mathrm{g} / \mathrm{ml}$ SOD (Fig. 1). A second smaller peak of light emission occurred 6-9 min after 48/80 stimulation which also was prevented by SOD.

Similar experiments were performed employing either unfractionated or mast cell-free preparations of rat peritoneal cells to determine the contribution of the contaminating cells to $\mathrm{O}_{2}^{-}$production after $48 / 80$ stimulation. $48 / 80$ stimulation of $1.25 \times 10^{6}$ mast cellfree peritoneal cells (either obtained from lavage of rats with prior peritoneal water lysis or from the interface layer of BSA-sedimented mixed cell suspensions) induced no cytochrome $c$ reduction (total $<1.5$ nmol) and no light emission above background. Unpurified rat peritoneal cells $\left(25 \times 10^{6}\right)$ which contained $1.25 \times 10^{6}$ mast cells reduced $33.1 \pm 3.0 \mathrm{nmol}$ cytochrome $c / 10^{6}$ mast cells after stimulation with $48 / 80$ $(1 \mu \mathrm{g} / \mathrm{ml})$ and generated $5,050 \pm 250 \mathrm{cpm} / 10^{6}$ mast cells. These findings suggest that the chemiluminescence appreciated after 48/80 stimulation of purified RPMC could be attributed primarily to the mast cells and that the contribution of the contaminating mononuclear and eosinophilic leukocytes was negligible.

The chemiluminescence of RPMC induced by $48 / 80$ was found to be both temperature and dose related. Whereas $1 \mu \mathrm{g} / \mathrm{ml} 48 / 80$ at $37^{\circ} \mathrm{C}$ caused a light emission of $4,762 \pm 221 \mathrm{cpm}$, at $30^{\circ} \mathrm{C}$ only $2,388 \pm 213 \mathrm{cpm}$ were emitted, and at $10^{\circ} \mathrm{C}$ no chemiluminescence was observed. Doubling the number of mast cells resulted 


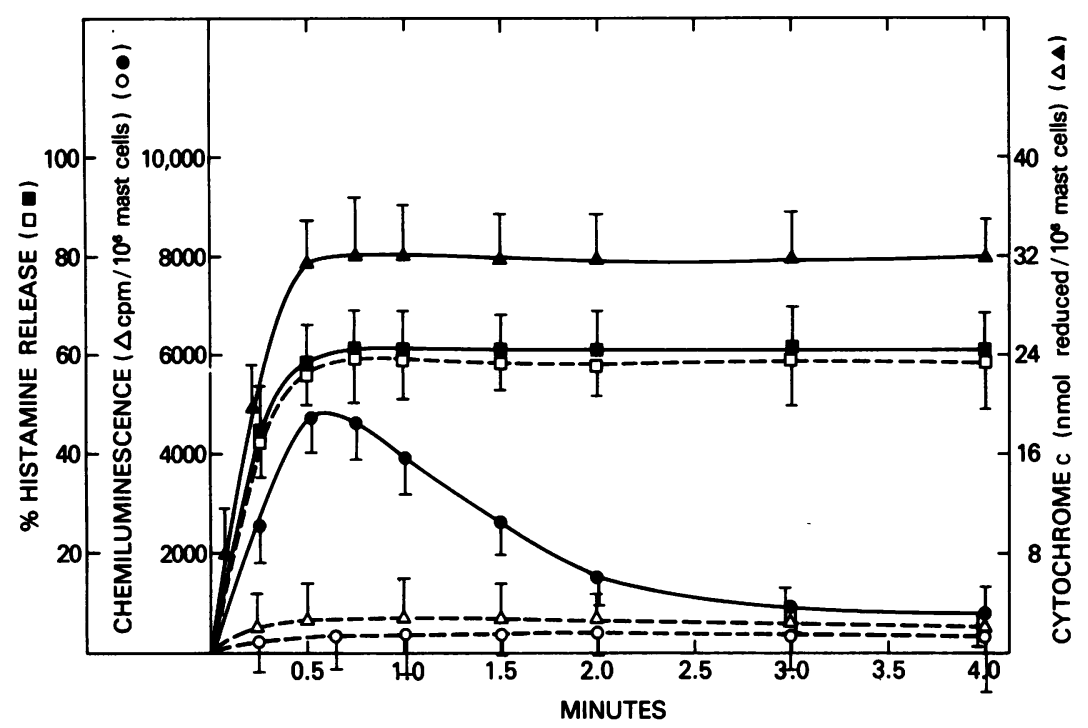

FIGURE 1 The time-course of the release of histamine and generation of $\mathrm{O}_{2}^{-}$from purified RPMC

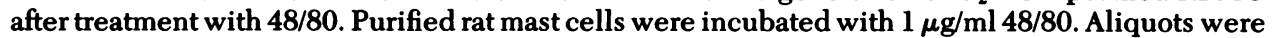
removed from $15 \mathrm{~s}$ to $15 \mathrm{~min}$ later, analyzed for histamine release, and cytochrome $c$ reduction (nmol reduced $/ 10^{6}$ mast cells) as described in Methods. Identical cell preparations were stimulated with $1 \mu \mathrm{g} / \mathrm{ml} \mathrm{48/80}$ and the generation of chemiluminescence quantitated in a liquid scintillation counter $\left(\Delta \mathrm{cpm} / 10^{6}\right.$ mast cells). The effect of SOD on histamine release, cytochrome $c$ reduction, and chemiluminescence was determined by adding $7 \mu \mathrm{g} / \mathrm{ml}$ SOD to the samples before challenge with 48/80. The data represents the mean \pm SEM of five experiments. Histamine release ( $\square$ ), plus SOD $(\square)$; chemiluminescence $(\Theta)$, plus SOD $(O)$; and cytochrome $c$ reduction $(\Delta)$, plus $\operatorname{SOD}(\Delta)$.

in a commensurate increase in chemiluminescence generated by $48 / 80$.

Anti-IgE-induced release. The relationship between the immunologic release of histamine and $\mathrm{O}_{2}^{-}$ by anti-IgE was next examined. Anti-IgE (1:5 and 1:10) produced a dose-related $(42.7 \pm 2.4$ and $26.7 \pm 1.9 \%$, respectively) release of histamine which was completed within 90-120 s (Fig. 2). Both chemiluminescence $\left(3,733 \pm 233\right.$ and $1,858 \pm 192 \mathrm{cpm} / 10^{6}$ mast cells $)$, and cytochrome $c$ reduction $36.4 \pm 2.0$ and $20.0 \pm 1.2$ $\mathrm{nmol} / 10^{6}$ mast cells) exhibited the same dose dependency (Fig. 2) and, in data not shown, the same time-course of release. Both chemiluminescence and cytochrome $c$ reduction induced by anti-IgE were blocked by SOD $(7 \mu \mathrm{g} / \mathrm{ml})$.

No chemiluminescence or cytochrome reduction occurred when mast cell-free peritoneal cells (obtained from rats treated with prior instillation of water intraperitoneally) were challenged with anti-IgE (1:5). Anti-IgE alone (without mast cells) did not generate either chemiluminescence or cytochrome $c$ reduction.

Isolated rat mast cell granules. To further explore the relationship between the secretion of histamine and $\mathrm{O}_{2}^{-}$generation, secretory granules were isolated from purified mast cells. The osmotic lysis of RPMC and their granular constituents results in membranefree granules composed of a matrix to which histamine and other secretory products are attached by ionic

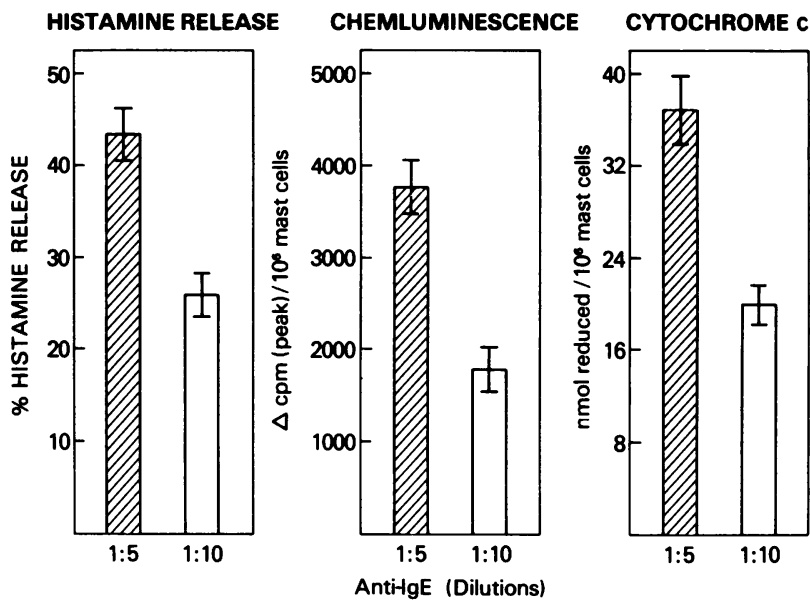

Figure 2 The dose-response relationship between sheep anti-rat IgE and the release of histamine as well as generation of chemiluminescence, and cytochrome $c$ reduction from rat peritoneal mast cells. Purified rat mast cells were incubated with 1:5 or 1:10 dilutions of sheep anti-rat IgE. Both histamine release and cytochrome $c$ reduction (nmol reduced/ $10^{6}$ mast cells) were determined in the same samples assayed $15 \mathrm{~min}$ after anti-IgE challenge of mast cells in buffer containing cytochrome $c(0.1 \mathrm{mM})$. The chemiluminescence was analyzed kinetically and describes the peak light emission $\left(\Delta \mathrm{cpm} / 10^{6}\right.$ mast cells) which was appreciated $45-90 \mathrm{~s}$ after antigen challenge. The data represents the mean $\pm S E M$ of four experiments. Both cytochrome $c$ reduction and chemiluminescence were prevented by the presence of SOD $(7 \mu \mathrm{g} / \mathrm{ml})$. 
charge (noncovalent). Examination of these preparations by electron microscopy revealed a uniform preparation of granules free of membranes with minimal contamination by nuclear debris. The addition of free cations displaces the bound histamine into the supernate $(34,38,39)$. Secretory granules isolated from $5 \times 10^{6}$ RPMC were examined for their content of histamine and their capacity to generate $\mathrm{O}_{2}^{-}$after the addition of cations (Table I). Resuspension of the isolated granules in Tyrode's buffer induced $99.5 \%$ release of the bound histamine $(50 \pm 2 \mu \mathrm{g})$ representing $41.6 \%$ of the histamine contained by $5 \times 10^{6}$ mast cells. In a similar fashion, the addition of buffer to a portion of the isolated granules generated a light emission of $2,400 \pm 294 \mathrm{cpm}$ which represented $49.5 \%$ of the light emission induced by $1 \mu \mathrm{g} / \mathrm{ml} 48 / 80$ interacting with $5 \times 10^{6}$ mast cells (the starting pool of intact cells). The addition of buffer to isolated granules also induced cytochrome $c$ reduction $(12.4 \pm 1.2 \mathrm{nmol})$ which represented $34.0 \%$ of the reducing capacity of the starting pool of cells.

Human basophils. Hypaque-Ficoll-fractionated human leukemic basophils (75\% purity, $5 \times 10^{6}$ basophils) challenged with 1:500 rabbit anti-human IgE were found to release $41.5 \pm 4.2 \%$ of their histamine, to generate a peak light emission of $2,300 \pm 105 \mathrm{cpm} / 10^{6}$ basophils and to reduce $18.1 \pm 2.2 \mathrm{nmol}$ cytochrome $c / 10^{6}$ basophils within $2 \mathrm{~min}$ of stimulation at $37^{\circ} \mathrm{C}$ (Fig. 3). A second smaller peak of light emission was noted 7-10 min after anti-IgE challenge. The same number $\left(5 \times 10^{6}\right)$ of human polymorphonuclear leukocytes obtained by Hypaque-Ficoll fractionation of nor- mal leukocytes did not generate light emission above background after stimulation with the rabbit antihuman IgE (1:500). The rabbit anti-human IgE alone did not generate chemiluminescence or reduce cytochrome $c$.

Human lung fragments. Sensitized human lung fragments stimulated with $0.5 \mu \mathrm{g} / \mathrm{ml}$ ragweed antigen E released $20.7 \pm 1.5 \%$ of their histamine, produced a peak light emission of $2,010 \pm 110 \mathrm{cpm}$, and reduced $20.4 \pm 1.0 \mathrm{nmol}$ cytochrome $c$ (Fig. 4). Reaction of lung fragments with 1:50 rabbit anti-human IgE produced a similar release of histamine $(26.6 \pm 0.4 \%)$, peak of chemiluminescence $(1,780 \pm 170 \mathrm{cpm})$, and cytochrome $c$ reduction $(23.6 \pm 1.6 \mathrm{nmol})$. Lung tissue which was not passively sensitized by ragweed antigen $E$ did not generate chemiluminescence or reduce cytochrome $c$ when incubated with $0.5 \mu \mathrm{g} / \mathrm{ml}$ ragweed antigen $\mathrm{E}$.

Detection of SOD. Because SOD is a widely distributed enzyme and is capable of preventing the $\mathrm{O}_{2}^{-}$:mediated reactions as described herein, the possible presence of SOD in mast cells and basophils was examined. Purified (>90\%) RPMC ( 1.25 $\left.\times 10^{6}\right)$ and partially purified $(75 \%)$ human basophils $\left(5 \times 10^{6}\right)$ were lysed in distilled water by both sonication and freeze-thawing. The lysates were electrophoresed into acrylamide gels to determine if they were capable of preventing NBT reduction. Both the mast cell and basophil preparations contained SOD (Fig. 5) by this assay.

The subcellular localization of this enzyme was next investigated. The supernate from intact RPMC treated with anti-IgE contained not only histamine and $\mathrm{O}_{2}^{-}$

TABLE I

The Detection of Histamine and Superoxide in Isolated Rat Mast Cell Granules

\begin{tabular}{|c|c|c|c|c|c|}
\hline \multicolumn{2}{|c|}{ Histamine } & \multicolumn{2}{|c|}{ Chemiluminescence } & \multicolumn{2}{|c|}{ Cytochrome $c$ reduction } \\
\hline Released & $\begin{array}{c}\text { Starting } \\
\text { pool }\end{array}$ & Peak & $\begin{array}{c}\text { Starting } \\
\text { pool }\end{array}$ & Nanomoles & $\begin{array}{c}\text { Starting } \\
\text { pool }\end{array}$ \\
\hline ng & $\%$ & $\Delta c p m$ & $\%$ & & $\%$ \\
\hline $5.0 \times 10^{4} \pm 0.2$ & 41.6 & $2,408 \pm 294$ & 49.5 & $12.4 \pm 1.2$ & 34.0 \\
\hline
\end{tabular}

Secretory granules from $5 \times 10^{6}$ purified rat mast cells were isolated by hypotonic lysis and differential centrifugation. The amount of histamine contained in the granular preparation was determined after the addition of $1 \mathrm{ml}$ of Tyrodes buffer to the granular pellet. Similarly, the generation of chemiluminescence and cytochrome $c$ reduction were determined after the addition of Tyrode's buffer to the granules.

The content of histamine in the staring pool was determined by measuring the amount of histamine in an aliquot of the purified mast cell pool before granular isolation. The starting pool for chemiluminescence generation and cytochrome $c$ reduction was determined by treating $5 \times 10^{6}$ purified rat mast cells with $1 \mu \mathrm{g} / \mathrm{ml}$ $48 / 80$ and measuring the quantity of superoxide generated. The quantity of histamine released and superoxide generated from the secretory granules was compared with the starting pool of mast cells and was expressed as the percentage of starting pool.

The data represents the mean \pm SEM of three experiments. 


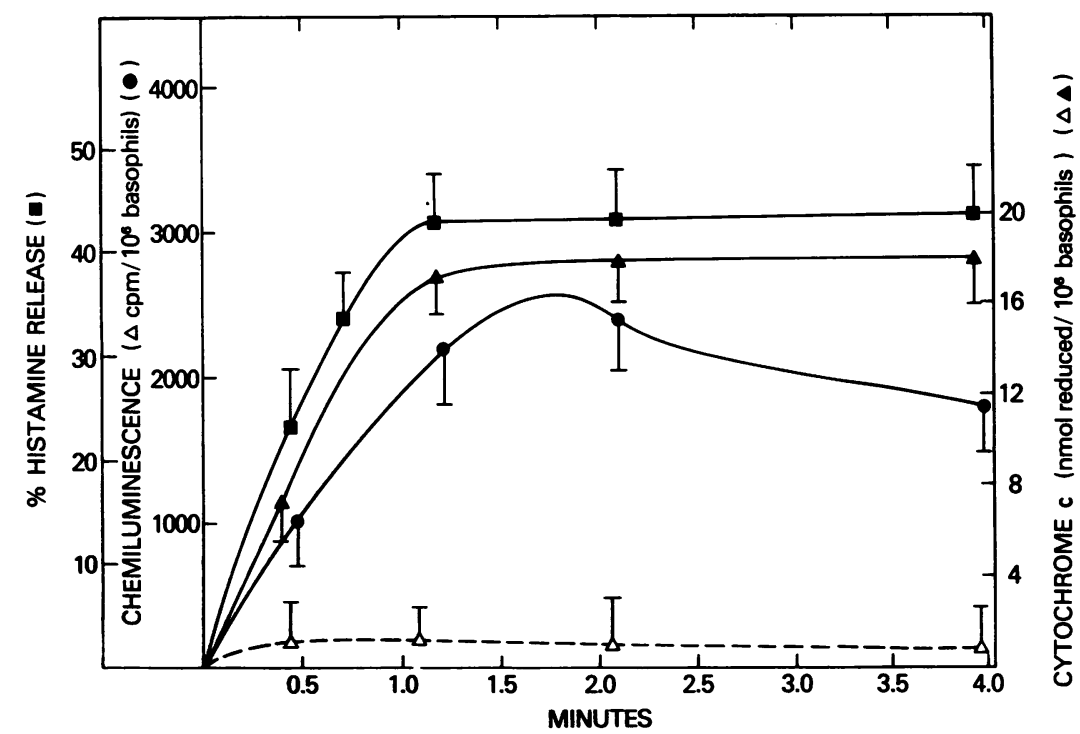

Figure 3 The time-course of the release of histamine and generation of $\mathrm{O}_{2}^{-}$from purified human leukemic basophils after treatment with rabbit anti-human IgE. Human leukemic basophils were incubated with a 1:500 dilution of rabbit anti-human IgE. Aliquots were removed from 15s to 22 min later and analyzed for histamine release and cytochrome $c$ reduction (nmol reduced/106 basophils). Identical cell preparations were stimulated with anti-IgE and chemiluminescence $(\Delta \mathrm{cpm} /$ $10^{6}$ basophils) was measured as described in Methods. The data represents the mean $\pm \mathrm{SEM}$ of two experiments. The effect of SOD on cytochrome $c$ reduction was determined by addition of SOD $(7 \mu \mathrm{g} / \mathrm{ml})$ to the samples before challenge with anti-IgE. Histamine release $(\square)$; chemiluminescence (O); and cytochrome $c$ reduction $(\Delta)$, plus SOD $(\Delta)$.

HISTAMINE RELEASE

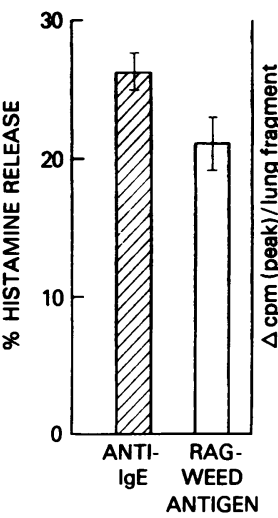

CHEMILUMINESCENCE

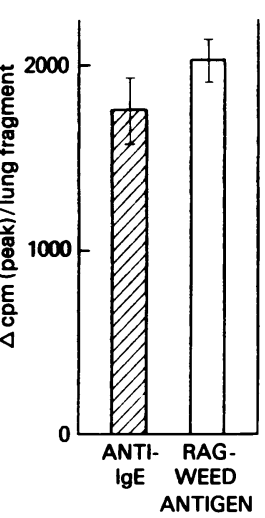

CYTOCHROME c

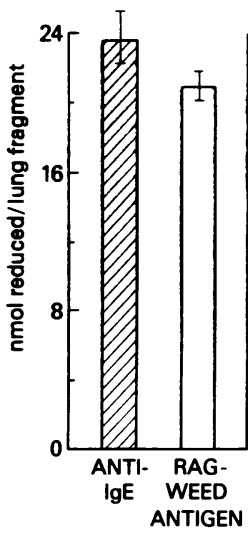

FIGURE 4 The generation of $\mathrm{O}_{2}^{-}$and release of histamine from IgE-sensitized human lung tissue by antigen or anti-IgE. IgEsensitized human lung fragments were incubated with either 1:50 rabbit anti-human IgE or $0.5 \mu \mathrm{g} / \mathrm{ml}$ ragweed antigen $\mathrm{E}$. Both histamine release and cytochrome $c$ reduction $(\mathrm{nmol}$ reduced/200 $\mathrm{mg}$ lung fragment) were determined $30 \mathrm{~min}$ after challenging lung fragments in buffer containing cytochrome $c(0.1 \mathrm{mM})$. The chemiluminescence represents the peak light emission $(\Delta \mathrm{cpm} / 200 \mathrm{mg}$ lung fragment) and was appreciated $60-120 \mathrm{~s}$ after antigen challenge. Both cytochrome $c$ reduction and chemiluminescence were prevented by the presence of SOD $(7 \mu \mathrm{g} / \mathrm{ml})$. The data represents the mean \pm SEM of three experiments.

but also SOD as assessed by the acrylamide/NBT system suggesting that SOD was located in the secretory granule (Fig. 5). Therefore, secretory granules from RPMC were isolated and studied. SOD was detected by two independent assays: $(a)$ the acrylamide/ NBT (Fig. 5) and (b) the xanthine/xanthine oxidase systems. The quantity of SOD found in the granules was $2.8 \pm 0.4 \mathrm{ng} \mathrm{SOD} / \mu \mathrm{g}$ of granule protein.

\section{DISCUSSION}

The RPMC, human leukemia basophil, and human lung mast cell after either immunologic or nonimmunologic stimulation have been shown to simultaneously release histamine and to generate the superoxide radical $\mathrm{O}_{2}^{-}$as reflected in two independent assays: chemiluminescence and cytochrome $c$ reduction. The mast cell suspensions utilized in these experiments were always purified to $>90 \%$. As the contaminating cell types (mononuclears and eosinophils) are known to be capable of generating $\mathrm{O}_{2}^{-}(4,29-32)$, the cellular source of $\mathrm{O}_{2}^{-}$was further defined. Suspensions of mast cell-free rat peritoneal cells (either obtained from animals treated with intraperitoneal water (33) or the cells from the interface layer after BSA sedimentation) containing 70-75\% mononuclear and $25-30 \%$ eosinophilic polymorphonuclear leukocytes were exposed 


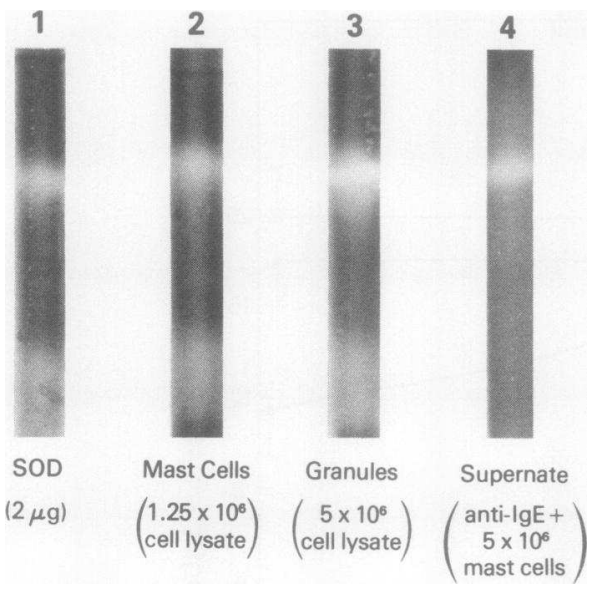

FIGURE 5 The detection of SOD by polyacrylamide gel electrophoresis in mast cell lysates, mast cell granules and supernate of activated mast cells. The achromatic band obtained from (1) SOD $(2 \mu \mathrm{g}),(2)$ the cell-free supernate obtained after lysis of $1.25 \times 10^{6} \mathrm{RPMC},(3)$ the granule-free supernate obtained from secretory granules isolated from 5 $\times 10^{6}$ RPMC, and (4) the supernate from anti-IgE (1:10) challenged RPMC $\left(5 \times 10^{6}\right)$.

to either $48 / 80$ or anti-IgE and no $\mathrm{O}_{2}^{-}$was generated. Thus, rat peritoneal cells in the absence of mast cells do not produce $\mathrm{O}_{2}^{-}$in response to $48 / 80$ or antiIgE. It was possible that the products of mast cell degranulation might have induced $\mathrm{O}_{2}^{-}$generation by the contaminating cells. However, there was no difference in the amount of $\mathrm{O}_{2}^{-}$produced after $48 / 80$ challenge of either $25 \times 10^{6}$ rat peritoneal cells containing $1.25 \times 10^{6}$ mast cells or an equivalent number of purified mast cells. These data suggest that under the conditions employed the cellular source of $\mathrm{O}_{2}^{-}$is the mast cell.

The noncytotoxic histamine-releasing agent $48 / 80$ ( $1 \mu \mathrm{g} / \mathrm{ml}$ ) induced histamine release and generated $\mathrm{O}_{2}^{-}$from purified RPMC in a kinetically related fashion; the appearance of both factors was appreciated within $15 \mathrm{~s}$, peaked within $30-60 \mathrm{~s}$, and plateaued thereafter. Although histamine release was unaffected by SOD, both chemiluminescence and cytochrome $c$ reduction were prevented by the enzyme which specifically dismutates $\mathrm{O}_{2}^{-}$. In addition, histamine release and $\mathrm{O}_{2}^{-}$generation induced by $48 / 80$ demonstrated parallel dose relationships and temperature sensitivities. Similarly, the immunologic release of histamine and $\mathrm{O}_{2}^{-}$from RPMC by anti-IgE also exhibited a parallel dose dependency and kinetic pattern of appearance. Therefore, histamine release and $\mathrm{O}_{2}^{-}$generation from RPMC appear to be closely related secretory phenomena.

The evidence that the secretory granule of the rat mast cell is one of the subcellular sources of $\mathrm{O}_{2}^{-}$production is suggested by the following observations: (a) the release of histamine and generation of $\mathrm{O}_{2}^{-}$in response to both $48 / 80$ and anti-IgE parallel each other in regard to, temperature dependency, dose-response relationships, and time-course of release; $(b)$ the $\mathrm{O}_{2}^{-}$-generating capability co-purifies with the mast cell secretory granule; and (c) this capacity can be eluted from isolated granules along with histamine by the addition of cations. Although it is conceivable that $\mathrm{O}_{2}^{-}$itself might secondarily localize to the secretory granule during the isolation process, this seems unlikely as $\mathrm{O}_{2}^{-}$anions are highly reactive, shortlived radicals (40) which would not be expected to persist through the isolation procedure. The possibility that additional adventitious factors might adhere to the granules during the isolation procedure and might be responsible for the subsequent generation of $\mathrm{O}_{2}^{-}$ cannot be definitively excluded without examining granules isolated with intact membranes $(39,41)$. However, the concordance observed between $\mathrm{O}_{2}^{-}$ production and histamine release from intact mast cells under a variety of conditions suggests that the factors responsible for $\mathrm{O}_{2}^{-}$production are of granular origin.

The close relationship between histamine release and $\mathrm{O}_{2}^{-}$production in rat mast cells was also extended to the two types of cells involved in human immediate hypersensitivity reactions - the peripheral basophilic leukocyte and the mast cell. Partially purified human basophils were found to liberate $\mathrm{O}_{2}^{-}$and histamine after immunologic (anti-IgE) stimulation. In addition, SOD was detected in leukemic basophil lysates. IgE-sensitized human lung tissue is known to release a variety of chemical mediators after immunologic challenge: histamine, slow-reacting substance of anaphylaxis, eosinophil chemotactic factor of anaphylaxis, the prostaglandins $E_{2}$ and $F_{2 \alpha}$ as well as thromboxanes $A_{2}$ and $B_{2}(16)$. In addition to these mediators of inflammation, the potentially destructive oxido-reductant $\mathrm{O}_{2}^{-}$was also found to be generated in the secretory reaction initiated by either antigen-IgE interaction or a reversed anaphylactic mechanism employing anti-IgE. The amount of $\mathrm{O}_{2}^{-}$generated by intact lung fragments in response to these stimuli might well have been underestimated. The submucosal and perivascular localization of mast cells in lung tissue would require diffusion of the short-lived $\mathrm{O}_{2}^{-}$ into the alveolar spaces for detection. Therefore, the chemiluminescence and cytochrome $c$ reduction were probably partially obscured by self absorption. That the origin of the $\mathrm{O}_{2}^{-}$is the mast cell is suggested by the specificity of the stimulating agents employed. Antigen $E$ challenge of unsensitized lung failed to produce $\mathrm{O}_{2}^{-}$generation (or histamine release) while the IgE molecule required for both stimulating agents has been detected only on mast cells, basophils, and plasma cells (42). These arguments notwithstanding, it 
is possible that the $\mathrm{O}_{2}^{-}$reflects a secondary consequence of mediator interaction with the heterogeneous cell types of which intact lung fragments are composed.

The generation of $\mathrm{O}_{2}^{-}$(as measured by cytochrome $c$ reduction) by mast cells activated by anti-IgE averaged $36.4 \pm 2.0 \mathrm{nmol} / 10^{6} \mathrm{RPMC}(n=4)$ and was completed within $60 \mathrm{~s}$. Similar anti-IgE stimulation of basophils generated $18.1 \pm 2.2 \mathrm{nmol} / 10^{6}$ basophils $(n=2)$ within the same time period. In comparison, mononuclear cells undergoing phagocytosis produce $20 \mathrm{nmol}$ cytochrome $c$ reduced $/ 10^{6}$ monocytes within $10 \mathrm{~min}$ (29). The quantity of cytochrome $c$ reduced by polymorphonuclear leukocytes at $10 \mathrm{~min}$ after initiation of phagocytosis averages $30-32 \mathrm{nmol} / 10^{6}$ polymorphonuclear leukocytes $(21,29,31)$.

The chemiluminescence of activated mast cells peaks at $4,000-5,000 \mathrm{cpm} / 10^{6}$ mast cells within $30-$ $90 \mathrm{~s}$, and basophils at $2,000-3,000 \mathrm{cpm} / 10^{6}$ basophils $90-120 \mathrm{~s}$ of activation. This is comparable to zymosanactivated mononuclear cells $\left(2,500-12,000 \mathrm{cpm} / 10^{6}\right.$ mononuclear cells) peaking at 8-30 min (29, 30, 32) and less than the amount generated by human polymorphonuclear leukocytes phagocytosing zymosan $\left(23,000-70,000 \mathrm{cpm} / 10^{6}\right.$ polymorphonuclear leukocytes) peaking at 8-20 min (29-32) after phagocytosis. Both rat mast cell and human basophils produce a second smaller peak of light emission 6-9 min after activation. This delayed luminescence was not associated with further reduction of cytochrome $c$ and may reflect either non- $\mathrm{O}_{2}^{-}$-mediated light emission or secondary excitations resulting from the initial peak of $\mathrm{O}_{2}^{-}$generation (43). The capacity of SOD to prevent this second light emission suggests the latter explanation.

SOD, the enzyme which specifically dismutates $\mathrm{O}_{2}^{-}$and hence may block its deleterious effects in tissues, was examined by its inhibition of both NBT reduction on acrylamide gels and cytochrome $c$ reduction produced by the xanthine/xanthine oxidase system. SOD was detected not only in the isolated granule fraction of RPMC but also in the supernate of anti-IgE stimulated purified rat mast cells. These data suggest that SOD may also be a granule-derived secretory product of immediate hypersensitivity reactions.

Therefore the reaction between mast cell or basophil-bound IgE antibodies, and immunologic or nonimmunologic activation initiates a secretory process which results in the release of the recognized chemical mediators, as well as SOD and the generation of $\mathrm{O}_{2}^{-}$. The role of $\mathrm{O}_{2}^{-}$in human inflammatory states must be extended to include both IgE-dependent reactions and hypersensitivity states involving mast cells or basophils. These observations may be important clues to the pathogenesis of the late IgEdependent cutaneous reaction $(44,45)$, the 4-6-h delayed bronchial response to provocative challenge (46), and the cutaneous basophil hypersensitivity reaction $(47,48)$. The role of mast cells in regards to parasitic infestations may be particularly relevant. Certain helminths are known to produce massive IgE production (49); mast cells have recently been observed to adhere to schistosomula through a $\mathrm{C}_{3}$ receptor (50); and preliminary evidence from our laboratory demonstrates $\mathrm{O}_{2}^{-}$production from these adherent mast cells.

\section{ACKNOWLEDGMENTS}

The authors gratefully acknowledge the expert advice of Doctors Robert C. Allen, Aaron J. Marcus, and David Alling; the excellent assistance of Dr. Alan Rosenthal, Mr. Thomas Blake, and Ms. Kerstin Cehrs in the microscope analyses of the preparations; and the expert secretarial assistance of Ms. Madeline Lee in the preparation of this manuscript.

\section{REFERENCES}

1. Allen, R. C., R. L. Stjernholm, and R. H. Steele, 1972. Evidence for the generation of an electronic stimulation state(s) in human polymorphonuclear leukocytes and its participation in bactericidal activity. Biochem. Biophys. Res. Commun. 47: 679-684.

2. Babior, B. M., R. S. Kipnes, and J. T. Curnutte. 1973. Biological defense mechanisms. The production by leukocytes of superoxide a potential bactericidal agent. J. Clin. Invest. 52: 741-744.

3. Curnutte, J. T., and B. M. Babior. 1974. Biological defense mechanisms. The effect of bacteria and serum on superoxide production by granulocytes.J. Clin. Invest. 53: $1662-1672$.

4. Drath, D. B., and M. L. Karnovsky. 1975. Superoxide production by phagocytic leukocytes. J. Exp. Med. 141: $257-262$.

5. Johnston, R. B., Jr., B. B. Keele, H. P. Mistra, J. E. Lehmeyer, L. S. Webb, R. L. Baehner, and K. V. Rajagopalan. 1975. The role of superoxide anion generation in phagocytic bactericidal activity. Studies with normal and chronic granulomatous disease leukocytes. J. Clin. Invest. 55: 1357-1372.

6. Weening, R. S., R. Wever, and D. Roos. 1975. Quantitative aspects of the production of superoxide radicals by phagocytosing leukocytes. J. Lab. Clin. Med. 85: 245252.

7. Curnutte, J. T., D. M. Whitten, and B. M. Babior. 1974. Defective superoxide production by granulocytes from patients with chronic granulomatous disease. $N$. Engl. J. Med. 290: 593-597.

8. Klebanoff, S. J. 1975. Antimicrobial mechanism in neutrophilic polymorphonuclear leukocytes. Semin. Hematol. 12: 117-142.

9. Fairshter, R. D., and A. F. Wilson. 1975. Paraquat poisoning: manifestations and therapy. Am. J. Med. 59: $751-753$.

10. McCord, J. M., and I. Fridovich. 1969. The utility of superoxide dismutase in studying free radical reactions. J. Biol. Chem. 244: 6056-6063.

11. Ishizaka, I., K. Ishizaka, S. G. O. Johansson, and H. Benich. 1969. Histamine release from human leukocytes by anti-IgE antibodies. J. Immunol. 102: 884-892.

12. Stechschulte, D. J., K. F. Austen, and K. J. Bloch. 1967. Antibodies involved in antigen-induced release of slow 
reacting substance of anaphylaxis (SRS-A) in the guinea pig and rat. J. Exp. Med. 125: 127-147.

13. Wasserman, S. I., E. J. Goetzl, and K. F. Austen. 1974. Preformed eosinophilic chemotactic factor of anaphylaxis (ECF-A). J. Immunol. 112: 351-368.

14. Becker, E. L., and P. M. Henson. 1973. In vitro studies of immunologically induced secretion of mediators from cells and related phenomena. Adv. Immunol. 17: 93-193.

15. Sullivan, T. J., and C. W. Parker. 1976. Pharmacologic modulation of inflammatory mediator release by rat mast cells. Am. J. Pathol. 85: 437-463.

16. Austen, K. F., and R. P. Orange. 1975. Bronchial asthma: the possible role of the chemical mediators of immediate hypersensitivity in the pathogenesis of subacute chronic disease. Am. Rev. Respir. Dis. 112: 423-436.

17. Peterson, C. 1974. Role of energy metabolism in histamine release. A study on isolated rat mast cells. Acta Physiol. Scand. 92 (Suppl. 413): 2-34.

18. Diamant, B. 1975. Energy production in rat mast cells and its role for histamine release. Int. Arch. Allergy Appl. Immunol. 49: 155-171.

19. Chakravarty, N., and E. Zeuten. 1965. Respiration of rat peritoneal mast cells. J. Cell Biol. 25: 113-121.

20. Chakravarty, N. 1965. Glycolysis in rat peritoneal mast cells. J. Cell Biol. 25: 123-128.

21. Cheson, B. D., R. L. Christensen, R. Sperling, B. E. Kohler, and B. M. Babior. 1976. The origin of the chemiluminescence of phagocytosing granulocytes. J. Clin. Invest. 58: 789-796.

22. Beauchamp, C., and I. Fridovich. 1971. Superoxide dismutase: Improved assays and an assay applicable to acrylamide gels. Anal. Biochem. 44: 276-287.

23. McCord, J. M., and I. Fridovich. 1969. Superoxide dismutase. An enzymatic function for erythrocuprein (hemocuprein). J. Biol. Chem. 244: 6049-6055.

24. Bergmeyer, H. U., E. Bernt, and B. Hess. 1965. Lactic dehydrogenase. In Methods in Enzymatic Analysis. H. U. Bergmeyer, editor. Academic Press, Inc. New York. 736-743.

25. Merchant, D. J., R. H. Kahn, and W. H. Murphy, Jr. 1960. In Handbook of Cell and Organ Culture. Burgess Publishing Co., Minneapolis, Minn. 50.

26. Webb, R. L. 1931. Peritoneal reactions in the white rat with special reference to the mast cells. Am. J. Anat. 49: 283-331.

27. Padawar, J., and A. S. Gordon. 1956. Cellular elements in the peritoneal fluid of some mammals. Anat. Rec. 124: 209-221.

28. Sullivan, T. J., K. L. Parker, W. Stenson, and C. W. Parker. 1975. Modulation of cyclic AMP in purified rat mast cells. I. Responses to pharmacologic, metabolic, and physical stimuli. J. Immunol. 114: 1473-1479.

29. Johnson, R. B., Jr., J. E. Lehmeyer, and L. A. Guthrie. 1976. Generation of superoxide anion and chemiluminescence by human monocytes during phagocytosis and on contact with surface-bound immunoglobulin G. J. Exp. Med. 143: 1551-1556.

30. Sagone, A. L., Jr., G. W. King, and E. N. Metz. 1976. A comparison of the metabolic response to phagocytosis in human granulocytes and monocytes. J. Clin. Invest. 57: 1352-1358.

31. Rosen, H., and S. J. Klebanoff. 1976. Chemiluminescence and superoxide production by myeloperoxidase deficient leukocytes. J. Clin. Invest. 58: 50-60.
32. Nelson, R. D., E. L. Mills, R. L. Simmons, and P. G. Quie. 1976. Chemiluminescence response of phagocytosing human monocytes. Infect. Immun. 14: 129-134.

33. Fawcett, D. 1955. An experimental study of mast cell degranulation and regeneration. Anat. Rec. 121: 29-43.

34. Uvnäs, B., C. H. Åborg, and A. Bergendorff. 1970. Storage of histamine in mast cells. Evidence for an ionic binding of histamine to protein carboxyls in the granule heparinprotein complex. Acta Physiol. Scand. 78 (Suppl. 336): 3-26.

35. Kaliner, M., R. P. Orange, and K. F. Austen. 1972. Immunological release of histamine and slow reacting substance of anaphylaxis from human lung. IV. Enhancement by cholinergic and alpha adrenergic stimulation. J. Exp. Med. 136: 556-567.

36. Fridovich, I. 1970. Quantitative aspects of the production of superoxide anion radical by milk xanthine oxidase. $J$. Biol. Chem. 245: 4053-4057.

37. Davis, B. J. 1964. Disc electrophoresis. II. Method and application to human serum proteins. Ann. N. Y. Acad. Sci. 121: 404-427.

38. Lagunoff, D. M., M. T. Phillips, O. A. Iseri, and E. P. Benditt. 1964. Isolation and preliminary characterization of rat mast cell granules. Lab. Invest. 13: 1331-1344.

39. Anderson, P., P. Röhlich, S. A. Slorach, and B. Uvnäs. 1974. Morphology and storage properties of rat mast cell granules isolated by different methods. Acta Physiol. Scand. 91: 145-153.

40. Bors, W., M. Saran, E. Lengfelder, R. Spöttl, and C. Michel. 1974. The relevance of the superoxide anion radical in biological systems. Curr. Top. Radiat. Res. Q. 9: 247-307.

41. Grosman, N., and B. Diamant. 1976. Studies on histamineretaining granules obtained from isolated rat mast cells. Agents and Actions. 6: 394-401.

42. Tada, T., and K. Ishizaka. 1970. Distribution of $\gamma-E$ forming cells in lymphoid tissues of the human and monkey. J. Immunol. 104: 377-387.

43. Nelson, R. D., M. Herron, R. L. Simmons, and P. G. Quie. 1977. Identification of conditions which influence the chemiluminescence response of human leukocytes. Fed. Proc. 36: 1071. (Abstr.)

44. Dolovich, J., F. E. Hargreave, R. Chalmers, K. J. Shier, J. Gauldie, and J. Bienenstock. 1973. Late cutaneous allergic responses in isolated IgE-dependent reactions. J. Allergy Clin. Immunol. 52: 38-46.

45. Solley, G. O., G. J. Gleich, R. E. Jordon, and A. L. Schroeter. 1976. The late phase of the immediate wheal and flare skin reaction. Its dependence upon IgE antibodies. J. Clin. Invest. 58: 408-420.

46. Pepys, J., M. Chan, F. E. Hargreave, and D. S. McCarthy. 1968. Inhibitory effects of disodium cromoglycate on allergen-inhalation tests. Lancet. II: 134-137.

47. Askenase, P. W., J. D. Haynes, and B. J. Hayden. 1976. Antibody-mediated basophil accumulations in cutaneous hypersensitivity reactions of guinea pigs.J. Immunol. 117: 216-224.

48. Dvorak, H. F. 1976. Cutaneous basophil hypersensitivity. J. Allergy Clin. Immunol. 58: 229-240.

49. Ogilvie, B., and V. E. Jones. 1973. Immunity in the parasitic relationship between helminths and host. Prog. $\mathrm{Al}$ lergy. 17: 93-144.

50. Sher, A. 1976. Complement-dependent adherence of mast cells to schistosomula. Nature (Lond.). 263: 334-336. 